\section{Platão. Crátilo, ou sobre a correç̧ão dos nomes. Texto bilíngue grego-português, tradução de Celso de Oliveira Vieira, apresentação de Miriam Campolina, introdução de Marcelo P. Marques. S. Paulo: Paulus, 2014. 103 p.}

* Universidade Federal do Ceará.
A tradução do diálogo Crátilo, de Platão, realizada por Celso Vieira a partir da edição de J. Burnet (PLATONIS. Opera. OUP., 1903), além de constituir uma novidade de relevo, apresenta particularidades que merecem recensão, às quais passo a fazer referência.

1. Todo o trabalho parece ser movido por um anseio de originalidade que leva o tradutor a correr riscos que poderão por em risco a compreensão de um diálogo subtil como o Crátilo. À partida, a opção por verter a segunda pessoa do singular - "tu" - por "você" cria algumas situações que dificultam o cotejo com a generalidade das traduções e comentários correntes do diálogo (p. ex., "O nome 'Hermógenes' não é o seu, nem se todos os humanos lhe chamam com ele": $\left.383 \mathrm{~b} 7-8^{1}\right)$.

Associadas a esta opção pela coloquialidade, manifestamse ainda duas tendências contraditórias que criam situações por vezes estranhas. Se, por um lado, o Autor da tradução mostra preferência pelo uso de termos correntes (p. ex. ponêron - "mau" por "imprestável": 386b1, 3, 11, d5), por outro, verte a terminologia da onto-epistemologia platónica, consagrada pela generalidade das traduções correntes, por um conjunto de termos e expressões que o leitor dificilmente relacionará com ela. Passo a apresentar alguns exemplos:
'Eidos' ("forma”, “ideia”) é traduzido por "especificação" (389b3, 10, 390a6, b1, e3, 440b1), e o verbo 'oida', eidenai (“saber") por "especificar", "especificação" (384c5-6; um bom exemplo será: Alla mên epithymô ge eidenai

\footnotetext{
${ }^{1}$ Nesta recensão, a numeração das páginas, parágrafos e linhas é a indicada pela edição de MÉRIDIER, L. Platon, Cratyle. Paris: Les Belles Lettres, 1961. Todas as citações são indicadas entre aspas; as traduções de nomes entre parênteses são as mais frequentemente usadas noutras traduções, em diversas línguas.
} 
- "Especificar me apetece": 391b6), tal como 'epistamai' ("saber", "conhecer", "compreender") por "ter consciência", "conscientizar" (390b6, c2, 6, d), ou tithêmi ("impor", "estabelecer" um nome), por "colocar" (385d9, 389a6), e ennoein ("ter em mente", "pensar", "considerar") por "inteligir" (397e6, 399a4).

Estas opções poderiam não ter grande consequência, se, ao longo de todo o diálogo, não se tornassem invariantes, como se de equivalências automáticas, ou quase, se tratasse. É ainda esse o caso de einai, ousia ("ser"/"existir", "essência"/ "existência") por "existir" e "existência", mesmo em contextos em que a ambiguidade predicativa/existencial deve ser observada (p. ex., "existissem", “existe”: 386d4-6; 387a3, 423e1-5). É também o caso de verbos relativos à prática linguística (p. ex., dêloô, dêloumai, dêlôma - "indicar", "significar", "significação"), por "evidenciar" (423a8, b5, 433b3), ou homologia, homologein ("concordar"), por "confirmar" (384d1).

Para um leitor desavisado, a quem talvez faltem motivos para matizar com precisão os significados atribuídos aos termos gregos, a chamada de atenção para a gravidade destas opções poderá parecer fastidiosa. No entanto, para qualquer estudioso do Crátilo, a consistência das opções terminológicas é imprescindível, se pretender captar o fio condutor do argumento do diálogo.

Será acima de tudo o caso dos termos indicados a seguir. Logos, legein, são sempre vertidos por "fala", "falar", desconsiderando a relevância da vertente escrita na avaliação da argumentação, que apresenta os nomes não apenas como "dados" (keimai, tithêmı) às "coisas", mas sobretudo como "escritos"2 (gegraptai: 432a2, 3). Por outro lado, essa opção ignora a diversidade das traduções habituais de logos, há muito impostas pela esmagadora maioria das traduções e comentários do diálogo ("discurso", "frase", "proposição", "enunciado", etc.), indiferentes à orientação para contextos orais ou escriturais. A tradução "dizer" é reservada para o verbo phêmi (383a4, 384c3, 392c5, passim), enquanto eipein, proseipein, são vertidos por "declarar", "proclamar" (p. ex., 388b4, 429e3, 6; neste passo, esquecendo a tradução capital "dirigir-se a"). Por sua vez, em passos chave da análise do enunciado, rhêma é traduzido por "verbo" (399b7, 421b3, 425a1, 431b5, 431b5, 6), "verbalização" (421e1, 2), esquecendo as traduções mais consensuais: "expressão", "locução", "frase", com o sentido amplo de "a 'outra parte' de um enunciado, a par de onoma” (ADEMOLLO, F. The Cratylus of Plato, A Commentary. Cambridge: CUP, 2011, p. 262-267).

Para além de constituir um erro traduzir a família dynatos, dynamai, dynamis ("capaz", "ser capaz", “capacidade”) por "princípio" (394b3-4, 405a1, 422c6, 435d2), notam-se ainda algumas escolhas equívocas, como: didaskein, didaskalikos ("ensinar", "que serve para ensinar"), por "informar" (388b13, e1, 435d4); ergon, dêmiourgos ("trabalho”, "obra”), por “produto", "produtor” (388d6, e1, 389a2); prosêkon, prosêkêo ("conveniente”, "requerido”), por "correspondente", “corresponder” (390a6, b1, 396a5, 429c2): erro reforçado pela tradução

\footnotetext{
2 A partir de 389d5, os "sons" (phthongous) associados às "sílabas" no desenvolvimento da "teoria mimética" são substituídos pelas "letras" (grammata: 390e4 ss.) que os representam.
} 
de homoios ("semelhante") por "igual", "igualdade" (430c12, 430a-b; quando a argumentação de Sócrates expressamente rejeita a "identidade" entre nome e nomeado: 432b-d). Menos grave será verter phaulos ("medíocre", "grosseiro") por "vulgar" (390d8, 401b7), ao contrário do que ocorre num ponto-chave da refutação do naturalismo de Crátilo (434c-435a), no qual a tradução de sklêrotês ("dureza") por "durabilidade" só serve para explorar a versão para português do problema criado pela equivalência - sklêrotês/sklêroter -, nos dialetos de Atenas e Erétria.

Devo ainda referir a escolha terminológica que me parece mais chocante em toda a tradução. Inspirado por uma relação duvidosa, provocada pela leitura dos manuscritos por J. Burnet - que a generalidade dos editores contesta -, o A. encontra apoio para uma tradução "controversa" (vide n.10, p. 30), repetida vezes sem conta ao longo de todo o diálogo. Favorecendo a leitura de 416b5 - Kai to kaloun ara kala -, em vez de - Kai to kalon ara kala -, que faz todo o sentido ("O belo [ergazetai: "produz": $\mathrm{d} 1$; vide c10-11] as coisas belas"), invoca o possível jogo de palavras entre kaloun ("chamador") e kala ("coisas belas") para propor a tradução de "belo", "coisas belas" (em muitos casos simplesmente "bem": kalôs), por "charmoso", "com charme" (390d6, 393c8, 400b1, 403e2, 411 a2 passim). Pergunto que sentido poderá ter para o leitor a tradução: "Tal qual o chamador [produz] as charmosas (416d5; n. 35, p. 67)?

Refiro de passagem algumas opções pontuais: manteia ("oráculo") por "lição"; agathos ("bom") por "excelente"; skopein ("investigar") por "averiguar"; sphodra ("muito") por "exuberante"; semnon ("sagrado", "solene") por "sinal" (392a2); desmos ("laço", "cadeia") por "detenção" (403c2). Também não posso deixar de registar três traduções de expressões correntes: moi pollakis pragmata parechei - ("muitas vezes parece que me crias dificuldades") por "exibe para mim muitas coisas" (427d3-4); dokeis ti moi legein ("Parece-me que dizes qualquer coisa"), por "A opinião que você fala é a minha" (438b4), ou phaiên ti moi legein (Id.) por "Parece que você diz algo para mim" (402c4). Noto ainda o exagero na versão do par categorial cheirous/ameinous ("piores/melhores"), por "inferiores" /"eminentes" (429a4-5) e "repulsivos"/“eminentes" (429b7-8).

Poderia ainda fazer referência a passos em que o trabalho do A. se afasta da linha consensualmente seguida por boas traduções, hoje correntes, em português, francês e inglês, pondo em risco a compreensão do texto (nomeadamente nos passos 432a-b e 440c). Não o faço aqui porque com isso ultrapassaria os limites da apreciação da tradução, para me intrometer no comentário do texto.

2. Noutra perspectiva, abordo agora a avaliação da tradução da longa secção do diálogo (38 pp., num total de 57 pp. de Stephanus) dedicada às etimologias de cerca de 140 nomes proeminentes da literatura e cultura gregas. Se as intenções que levam Sócrates a entregar-se à empresa têm sido objeto de discussão dos comentadores, muitos concordam que Platão apresenta os nomes como um sistema descritivo, articulado e coerente, cuja "concordância" (symphônia: 436b-d) permite justificar o parentesco semântico dos nomes 
pelas semelhanças fonéticas que os ligam. ${ }^{3}$ O problema reside em decidir de quê são os nomes descrições.

Se para Sócrates só podem ser entendidos como designações “daquilo que as coisas (pragmata) são" (ousia: 386d-e), para Crátilo devem “indicar as naturezas" (physeis) às quais "são dados" (keisthai: 429c). Portanto, enquanto o filósofo lhes confere um uso decididamente referencial, o seu interlocutor atribui-lhes um uso descritivo.

Haverá também que ter em conta os diversos aspectos pelos quais as etimologias podem ser entendidas e a finalidade que visam na argumentação desenvolvida por Sócrates. Alguma bibliografia recente defende o alcance filosófico e metodológico da secção (SEDLEY, D. Plato's Cratylus. Cambridge: CUP, 2003, p. 25-50, p. 75-122) seja ressaltando o seu valor como "exibição agonística" (BARNEY, R. Names and Nature in Plato's Cratylus. New York and London: Routlege, 2001, p. 60-68), seja notando o carácter sistemático da estruturação de uma "doxografia" da tradição grega, "articulando a investigação dos nomes com a das coisas” (F. Ademollo 2011, p. 189-191; p. 199-210). Quanto à finalidade que visam, pode-se condensá-la no comentário sintético de Ademollo: "a função de ao menos uma parte das etimologias é minar as bases do naturalismo enquanto finge pô-lo em prática" (208).

Esta breve digressão sobre o sentido da seção das etimologias visa um único objetivo: questionar a opção do A. da tradução por "verter [para o português brasileiro] jogos de palavras do grego antigo" (contracapa). Se a prolongada atenção que Platão lhes dedica visa tantas e tão distintas finalidades, não será a compreensão delas inviabilizada por essa versão para português (ou qualquer outra, em qualquer língua)? Não deixará essa opção o leitor impossibilitado de captar a amplidão e profundidade do programa de Platão no Crátilo?

3. Termino esta recensão com uma nota positiva. É sabido que as mais acerbas críticas ao trabalho dos tradutores de textos de filosofia antiga são motivadas por não passarem de cópias de outras traduções, quase sempre publicadas noutras línguas. Como as críticas acima apresentadas amplamente documentam, essa será a crítica que não pode ser feita a esta tradução.

Como afirmei acima, atribuo a maioria dos erros que imputei ao A. da tradução - se de fato devem ser contados como erros - ao que considero um excesso de originalidade, inapropriado na tradução de um texto clássico de filosofia. Todavia, a coerência com que essa originalidade é defendida, pela imposição de uma tradução "padrão" a cada termo e expressão questionável, com absoluta indiferença pelas opções correntemente aceitas e pela diversidade de contextos em que ocorrem, se errada, constitui prova de coerência e respeito pela opção assumida.

Recebido em: 3 de outubro de 2014

Aprovado em: 19 de julho de 2016

\footnotetext{
${ }^{3}$ Se, por um lado, a função do nome é imitar as coisas; por outro, cada nome é explicado pela sua relação - a um tempo fonética e semântica - seja com outros nomes, seja com as "expressões" (rhêmata) de que deriva.
} 